\section{Breast-milk Jaundice and Oral Contraceptives}

\author{
Y. K. WONG, B. S. B. WOOD
}

British Medical Fournal, 1971, 4, 403-404

\section{Summary}

Among breast-fed infants in the normal lying-in wards of a maternity hospital a significantly higher incidence of "idiopathic" jaundice was found in infants of mothers who had been receiving the contraceptive pill before the present pregnancy than in the infants whose mothers never had the pill. The pill became widely used in society at about the same time as breast-milk jaundice was first reported.

\section{Introduction}

Neonatal jaundice relating to breast-feeding was first recorded by Arias et al. (1963). Since then it has been shown that there is a higher incidence of jaundice in breast-fed than in bottle-fed infants, and that plasma bilirubin levels fell when some of the infants were taken off breast milk but rose or ceased to fall when they were returned to the breast (Newman and Gross, 1963; Arias and Gartner, 1964; Stiehm and Ryan, 1965; Arthur et al., 1966; Severi et al., 1970). Icterogenic milk has been shown to inhibit conjugation of bilirubin by human liver in vitro (Arias et al., 1964; Arthur et al., 1966; Ramos et al., 1966; Adlard and Lathe, 1970). From the icterogenic milk 3a20b pregnanediol was isolated and shown to inhibit glucuronyl transferase of guinea-pig liver (Arias et al., 1964). However, glucuronidation was not inhibited in human liver slices (Holton and Lathe, 1963; Adlard and Lathe, 1970) by 3a20b pregnanediol, nor was glucuronyl transferase inhibited, though in rat liver slices (Hargreaves and Piper, 1971) the secretion of bilirubin glucuronide was inhibited. It seems probable that other agents are involved but these have not yet been identified.

In the course of a study on breast-milk jaundice the impression was gained by one of us (Y.K.W.) that the condition may be related to mothers who had taken oral contraceptive pills. A prospective study was then carried out.

\section{Patients and Methods}

Unselected postnatal wards were visited at random intervals. Infants of low birth weight (less than $2.3 \mathrm{~kg}$ ), sick infants, infants of mothers with any clinical infection or diabetes mellitus, and infants with a positive direct Coombs test were excluded. The names of breast-fed infants who were 5 days or older were obtained and their mothers were asked whether they had ever been on any oral contraceptive pills. Mothers who had received other oestrogen-progesterone preparations or had had the pill for less than one full course were excluded

Special Care Baby Unit, Maternity Hospital, Birmingham B15 2TG Y. K. WONG, M.R.C.P., D.C.H., Research Registrar (Recipient of Research Grant from the Endowment Fund, United Birmingham Hospitals) B. S. B. WOOD, D.M., F.R.C.P., Consultant Paediatrician from the study, as were their infants. Mothers who had never been on the pill were called "No Pill." Those who had had the pill for one full course (21 days) or more were called "Pill."

The infants were classified according to the notes recorded by independent observers as follows:

Non-faundiced Infants. - These infants had never been jaundiced or their jaundice was slight and already fading by the fifth day of life.

faundiced Infants.-These infants had either an icterometer grading (Culley et al., 1960; Gosset, 1960) of three or more or a plasma bilirubin level, measured by the method of Scott (1959), of $10 \mathrm{mg} / 100 \mathrm{ml}$ or more on their fifth day.

Severely faundiced Infants. - These were infants whose plasma bilirubin levels were greater than $15 \mathrm{mg} / 100 \mathrm{ml}$ on their fifth or subsequent days of life.

\section{Results}

General Data on Mothers and Infants.-A total of 116 motherinfant pairs were examined during the period of study. No significant difference was found between the jaundiced and non-jaundiced infants comparing birth weight, gestation, sex ratio, birth rank, or the age of the mothers.

Incidence of Faundice and Maternal Pill Consumption.-There were 69 non-jaundiced and 47 jaundiced infants; 57 mothers had been on the pill and 59 had not. Of the 69 non-jaundiced infants $24(34.8 \%)$ mothers had been on the pill; of the 47 jaundiced infants $33(70 \cdot 2 \%)$ mothers had been on the pill. Table I shows the distribution. The result strongly suggests that there is a relationship between the pill and "idiopathic" jaundice in the breast-fed infants.

Severely faundiced Infants. - A total of 18 infants had plasma bilirubin levels of over $15 \mathrm{mg} / 100 \mathrm{ml}$ on fifth or subsequent

TABLE I-Distribution of Mothers and Infants

\begin{tabular}{|c|c|c|c|c|c|}
\hline \multirow{2}{*}{\multicolumn{3}{|c|}{ Mothers }} & \multicolumn{2}{|c|}{ Infants } & \multirow{3}{*}{$\begin{array}{r}\text { Total } \\
57 \\
59\end{array}$} \\
\hline & & & \multirow{2}{*}{$\begin{array}{c}\text { Jaundiced } \\
33 \\
14\end{array}$} & \multirow{2}{*}{$\begin{array}{c}\text { Non-jaundiced } \\
24 \\
45\end{array}$} & \\
\hline $\begin{array}{l}\text { Pill } \\
\text { No pill }\end{array}$ & $\because$. & $\because$. & & & \\
\hline & & $\ldots$ & 47 & 69 & 116 \\
\hline
\end{tabular}

$\chi^{2}$ (with Yates's correction $)=12.66 ; P<0.0005$.

TABLE II-Severely faundiced Infants

\begin{tabular}{l|c|c}
\hline & \multicolumn{2}{|c}{ Mothers } \\
\cline { 2 - 3 } & Pill & No Pill \\
\hline $\begin{array}{c}\text { All infants with plasma bilirubin level above } 15 \mathrm{mg} / 100 \\
\text { ml } \ldots \text {. }\end{array}$ & 14 & 4 \\
$\begin{array}{c}\text { All infants with plasma bilirubin level above } 15 \mathrm{mg} / 100 \\
\text { ml, excluding possible ABO blood group incompati- } \\
\text { bility and those less than } 3 \mathrm{~kg} \text { birth weight } \ldots\end{array}$ & 11 & 3 \\
\hline
\end{tabular}

days of life (Table II). Thus when the severely jaundiced infants are considered separately there is a similar relationship.

The mean duration of pill consumption of mothers with jaundiced infants was 24.4 months (S.D. $=21 \cdot 3$ ) and 18.6 months (S.D. $=17 \cdot 1$ ) in mothers with non-jaundiced infants. The differences are not significant. The mean interval between cessation of contraceptive pill and delivery in mothers with jaundiced infants was 18.8 months (S.D. $=11.2$ ) and 23.7 months (S.D. = 20.4) in mothers with non-jaundiced infants. The differences are not significant. 


\section{Discussion}

Oestriol given to neonates have been shown to increase plasma bilirubin levels (Lauritzen and Lehmann, 1967). When oestradiol was given to mothers 24 hours before delivery, the incidence and level of subsequent jaundice of the breast-fed neonate were found to be increased over the controls (Koivisto et al., 1971). It is, however, difficult to understand that maternal consumption of oral contraceptive pills for a varying duration and after a varying interval since cessation could have any effect on the breast-fed infant's liability to jaundice. The figures, however, speak for themselves.

It should be noted that the oral contraceptive pill came into increasingly widespread use in the U.S.A. from 1958 and in the U.K. from 1960 onwards and that breast-milk jaundice was first recorded in 1963.

It would be interesting to know if these results could be confirmed in other centres.

We are grateful to Dr. John Waterhouse for much help with the statistics. Professors John Edwards and George Knox kindly gave valuable criticism.

\section{References}

Adlard, B. P. F., and Lathe, G. H. (1970). Archives of Disease in Childhood, $45,186$.

Arias, I. M., and Gartner, L. M. (1964). Nature, 203, 1292.

Arias, I. M., Gartner, L. M., Seifter, S., and Furman, M. (1963). Presented at the 55th Annual Meeting of the American Society for Clinical Investigation; Atlantic City, New Jersey, 29 April 1963.

Arias, I. M., Gartner, L. M., Seifter, S., and Furman, M. (1964). Fournal of Clinical Investigation, 43, 2037.

Arthur, L. J. H., Bevan, B. R., and Holton, J. B. (1966). Developmental Medicine and Child Neurology, 8, 279.

Culley, P. E., Waterhouse, J. A. H., and Wood, B. S. B. (1960). Lancet, 1, 88. Gosset, I. H. (1960). Lancet, 1, 87.

Hargreaves, T., and Piper, R. F. (1971). Archives of Disease in Childhood, 46, 195.

Holton, J. B., and Lathe, G. H. (1963). Clinical Science, 25, 499.

Koivisto, M., Blanco-Sequeiros, M., Ojala, A., and Jarvinen, P. (1971). Thirteenth International Congress of Paediatrics, 1, 327.

Lauritzen, C., and Lehmann, W. D. (1967). Fournal of Endocrinology, 39, 183. Newman, A. J., and Gross, S. (1963). Pediatrics, 32, 995.

Ramos, A., Silverberg, M., and Stern, L. (1966). American fournal of Diseases of Children, 111, 353.

Scott, P. (1959). Nerosletter of the Association of Clinical Biochemists, No. 24, November, p. 11.

Severi, F., Rondini, G., Zaverio, S., and Vegni, M. (1970). Helvetica Paediatrica Acta, 5, 517.

Stiehm, E. R., and Ryan, J. (1965). American Fournal of Diseases of Children, $109,212$.

\section{MEDICAL MEMORANDA}

\section{Nephrotic Syndrome: A Complication of Secondary Syphilis}

\author{
M. D. HELLIER, A. D. B. WEBSTER, \\ A. J. M. F. EISINGER
}

British Medical Fournal, 1971, 4, 404-405

The association between secondary syphilis and the nephrotic syndrome is well recognized but very uncommon. Since Herrmann and Marr classified the renal complications of syphilis in 1935 about 30 cases have been recorded in the world literature. To our knowledge no case has been reported in the British literature during this time. As detailed histological appearances have been described on only three occasions (Brophy et al., 1964; Falls et al., 1965; Robins and Ladd, 1962) we feel it worth while reporting the following case.

\section{Case Report}

A 22-year-old woman was admitted to the Royal South Hants Hospital on 17 January 1969 for investigation of generalized oedema. Her initial complaint, two weeks previously, was of earlymorning facial swelling. During the following two weeks her arms and legs also became oedematous and her weight increased by

Department of Medicine, Royal South Hants Hospital, Southampton SO9

M. D. HELLIER, M.R.C.P., Senior House Officer (Present appointment : Lecturer, the Medical Unit, St. Bartholomew's Hospital, London EC1A 7BE)

A. J. M. F. EISINGER, M.R.C.P., Senior Registrar (Present appointment: Senior Registrar, the Royal Hospital, Sheffield S1 3SR)

Wessex Renal Unit, Portsmouth PO 36AF

A. D. B. WEBSTER, M.R.C.P., Registrar in Nephrology (Present appointment: Senior Registrar, Clinical Research Centre, Northwick Park Hospital, Middlesex)
$25 \mathrm{~kg}$. In association with these symptoms an irritant rash appeared on her body. She had been well before this episode and, in particular, there was no evidence of previous renal disease or of recent streptococcal infection. No medication of any kind had been given in the preceding few months. She was married with two children but was separated from her husband. Her two pregnancies, six and three years previously, had been uneventful and Wassermann reactions on both occasions were negative.

On admission she appeared pale and unwell, with a pyrexia of $100^{\circ} \mathrm{F}\left(37.8^{\circ} \mathrm{C}\right)$, pronounced periorbital oedema, and extensive pitting oedema from the waist downwards. There was no lymphadenopathy. The pulse was regular, $80 / \mathrm{min}$, and the blood pressure was 105/70 mm $\mathrm{Hg}$. The jugular venous pressure was not raised. Fine crepitations were heard at both lung bases. A red scaly macular rash covered the trunk but not the limbs. No abnormalities were found on neurological examination.

Laboratory investigations were: haemoglobin $10.5 \mathrm{~g} / 100 \mathrm{ml}$; W.B.C. $5,100 / \mathrm{mm}^{3}$ (36\% segmented neutrophils, $52 \%$ lymphocytes, $8 \%$ eosinophils); erythrocyte sedimentation rate $110 \mathrm{~mm} / \mathrm{hr}$ (Westergren); total serum protein $3.9 \mathrm{~g} / 100 \mathrm{ml}$ (albumin $0.8 \mathrm{~g} /$ globulin $3.1 \mathrm{~g}$ ); serum protein electrophoresis, diffuse increase in a2-globulin; serum cholesterol $325 \mathrm{mg} / 100 \mathrm{ml}$; serum creatinine $1.25 \mathrm{mg} / 100 \mathrm{ml}$; blood urea $54 \mathrm{mg} / 100 \mathrm{ml}$; serum electrolytes normal; antinuclear factor and L.E. cells not found. The urine deposit contained two red blood cells and four white cells per highpower field and some hyaline casts.

She was treated initially with frusemide but despite increasing doses continued to deteriorate. Three days after admission she developed bilateral pleural effusions with evidence of pneumonia. Treatment was supplemented with ampicillin and spironolactone. On 24 January positive serological results for syphilis were received and a course of procaine penicillin was started. Within three days she began to make a rapid recovery, and during the subsequent three weeks she lost $20 \mathrm{~kg}$ in weight and became oedema-free. The macular rash disappeared in a matter of days. Further serological examination confirmed syphilitic infection by showng a positive Venereal Disease Research Laboratory slide test, treponemal immobilization test, and fluorescent treponemal antibody test.

Despite the satisfactory clinical response gross proteinuria and hypoalbuminaemia persisted. In view of this a renal biopsy was performed early in April. A detailed report of the light and electron microscopical findings is given below. She was seen regularly as an outpatient after her discharge from hospital. Her clinical improvement continued and diuretics were stopped by the end of May. Since this time there has been no recurrence of oedema. On 29 July proteinuria persisted, with a serum albumin of $1.9 \mathrm{~g}$ / $100 \mathrm{ml}$. By October the serum albumin had returned to normal at 